\title{
Adrenal Cancer Pathologic Distant Metastasis TNM Finding v7
}

National Cancer Institute

\section{Source}

National Cancer Institute. Adrenal Cancer Pathologic Distant Metastasis TNM Finding v7. NCI Thesaurus. Code C89409.

A pathologic finding about one or more characteristics of adrenal cancer, following the rules of the TNM AJCC V7 classification system as they pertain to distant metastases. There is no pathologic M0 for adrenal cancer. (from AJCC 7th Ed.) 